\title{
National food policies in the Islamic Republic of Iran aimed at control and prevention of noncommunicable diseases
}

\begin{abstract}
Masoumeh Moslemi, ${ }^{1}$ Mehrnaz Kheirandish, ${ }^{2}$ Ramin Nezhad Fard Mazaheri, ${ }^{34}$ Hedayat Hosseini, ${ }^{5}$ Behrooz Jannat, ${ }^{1}$ Vahid Mofid, ${ }^{5}$ Atefeh Moghadd$\mathrm{am}^{6}$ and Nader Karimian ${ }^{6}$

${ }^{1}$ Halal Research Centre, Iran Food and Drug Administration, Tehran, Islamic Republic of Iran. ${ }^{2}$ Department of Assessment and Control of Prescribing and Use of Medicines and Health Products, Iran Food and Drug Administration, Tehran, Islamic Republic of Iran. ${ }^{3}$ Division of Food Microbiology, Department of Pathobiology, School of Public Health, Tehran University of Medical Sciences, Tehran, Islamic Republic of Iran. ${ }^{4}$ Food Microbiology Research Centre, School of Public Health, Tehran University of Medical Sciences, Tehran, Islamic Republic of Iran. ${ }^{5}$ Department of Food Science and Technology, National Nutrition and Food Technology Research Institute, Faculty of Nutrition Sciences and Food Technology, Shahid Beheshti University of Medical Sciences, Tehran, Islamic Republic of Iran. ${ }^{6}$ Department of Foods and Beverages, Iran Food and Drug Administration, Tehran, Islamic Republic of Iran. (Correspondence to: Mehrnaz Kheirandish: mehrnazkheirandish@gmail.com).
\end{abstract}

\begin{abstract}
Background: Diet plays an important role in the risk of noncommunicable diseases. In the Islamic Republic of Iran, national activities were started after release of the World Health Organization's (WHO) action plan on prevention and control of noncommunicable diseases.

Aims: This study describes national food policies implemented by the government in order to reduce noncommunicable diseases in the country in line with WHO action plan.

Methods: Newly adopted food standards and regulations linked to noncommunicable diseases from 2013 to 2018 were reviewed and the maximum permitted levels of salt and trans and saturated fats were compared in the old and new standards. Nutritional traffic light labelling to raise public awareness of healthy diets was evaluated.

Results: Fifteen food standards associated with eight food items that make up a large share of the daily Iranian food basket and three that make up a small share were evaluated. Policies on salt included reduction in maximum permitted percentage in bread, cheese and doogh (a fermented drink) to $1 \%, 3 \%$ and $0.8 \%$, respectively. For trans and saturated fats, maximum permitted percentages were set as $2-5 \%$ and $30-65 \%$ of edible oils and fats, respectively. Nutritional traffic light labelling, which indicates the content of salt, sugar, fat and trans fat in foods, has been mandatory for all foods since 2016.

Conclusions: In view of the polices implemented to reduce the salt and fat/oil content of foods, significant decreases in noncommunicable diseases are expected in coming years in the country. However, further studies are needed to show the effectiveness of the interventions.
\end{abstract}

Keywords: diet, nutrition policy, noncommunicable diseases, Iran

Citation: Moslemi M; Kheirandish M; Mazaheri R; Hosseini H; Jannat B; Mofid V; et al. National food policies in the Islamic Republic of Iran aimed at prevention of noncommunicable diseases. East Mediterr Health J. 2020;26(12):1556-1564. https://doi.org/10.26719/emhj.20.024

Received: 03/03/19; accepted: 02/09/19

Copyright (c) World Health Organization (WHO) 2020. Open Access. Some rights reserved. This work is available under the CC BY-NC-SA 3.0 IGO license (https://creativecommons.org/licenses/by-nc-sa/3.o/igo).

\section{Introduction}

Noncommunicable diseases (NCDs) are chronic disorders caused by non-infectious agents. NCDs kill 41 million people annually, which represents $71 \%$ of all deaths worldwide (1). Based on World Health Organization (WHO) reports, annual deaths from NCDs are mostly linked to cardiovascular diseases (44\%), cancers $(22 \%)$, respiratory diseases (10\%) and diabetes (4\%) (1). NCDs are an important health concern in the Islamic Republic of Iran; the annual death rate from NCDs represents about $82 \%$ of the total mortality in the country (2). National studies show a $14.5 \%$ increase in deaths from NCDs in the past 20 years (3). This is of concern, especially as the population is ageing.

Several factors should be considered when developing and implementing strategies to reduce NCDs. For example, diet, and preparation and consumption of foods vary in different societies and according to demographic, cultural and socioeconomic characteristics $(4,5)$. Therefore, one of the main global challenges in designing strategies to control and manage NCDs in large countries such as the Islamic Republic of Iran is modification of food traditions. Practical recommendations to follow a healthy lifestyle are regularly published by WHO. In 2013, WHO made a global call for a $25 \%$ decrease in premature deaths from NCDs in people aged 30-70 years by 2025 (6). Furthermore, Member States of WHO endorsed the 20132020 action plan that focuses on four behavioural risk factors for NCDs: unhealthy diet, harmful use of alcohol, insufficient physical activity and tobacco use. The action plan describes 25 indicators classified under nine targets $(3,6)$ to help countries develop their national strategies for decreasing NCDs. To respond to this call and the action plan, The Ministry of Health and Medical Education of Iran established the national NCD committee in 2015 with the aim of integrating all decisions and activities on the prevention and control of NCDs at the national level 
in line with the WHO global call. Because NCD mortality from other causes not included in WHO nine targets is high in the country, four further targets were added to the list by the health ministry. These targets were: zero trans fatty acids in all manufactured food products, reduced traffic injuries, reduced drug abuse and access to treatment for mental diseases.

Similar to other countries, dietary risk factors are significant contributors to NCDs in the Islamic Republic of Iran, and their assessment and management are fundamental to preventing NCDs $(3,7,8)$. Thus, close collaboration between the public sector, private health associations and the food industry is needed to establish healthy food policies to achieve national and international targets. In the Islamic Republic of Iran, the Food and Drug Administration is responsible for national food safety and, as a member of the national NCD committee, works closely with other key players in food and nutrition fields to improve the effectiveness of food policies and strategies linked to NCDs. Many interventions and factors have important roles in the prevention of NCDs, including food reformulation, labelling, monitoring, and public awareness and marketing (7). For example, socioeconomic factors, such as incentives to choose larger packages through advertisements and price encouragements, may negatively affect dietary patterns (9). To minimize the adverse effects of diet on the prevalence of NCDs in the Islamic Republic of Iran, international guidelines and recommendations on food intake were studied by stakeholders including regulatory experts such as risk managers and academic staff. As a result, the maximum permitted levels of salt and saturated and trans fatty acids in food in the national regulations were modified based on Iranian dietary patterns. These modifications were used for staple foods such as bread, dairy products and oil products. In parallel, to increase consumer awareness and its contribution to preventive mechanisms, a new graphical feature was designed and used on all food packaging - a nutritional traffic light.

In this study, policies and interventions adopted in the Islamic Republic of Iran to decrease NCDs following the WHO action plan were reviewed. As the Islamic Republic of Iran is a pioneer in the region in adopting measures to reduce NCDs, especially for trans fatty acids and nutritional traffic lights, we aimed to share our experiences in NCD control with other countries in the region.

\section{Methods}

In this study, a comprehensive review was carried out on newly adopted food standards and regulations by the Iran Food and Drug Administration and the Iran National Standards Organization which addressed the WHO target of a $25 \%$ decrease in premature deaths from NCDs by 2025 . First, food products associated to NCD policies were identified. Then, all relevant standards and regulations, including newly adopted or modified versions, were extracted from the official websites of the Iran Food and Drug Administration and Iranian National Standards
Organization. Furthermore, the maximum permitted levels of salt, and trans and saturated fats in old and revised standards were compared. The activities of the Iran Food and Drug Administration to raise public awareness about healthy food consumption were also assessed.

Since one of the nine NCD targets introduced by WHO is salt reduction and several national policies have been put in place to decrease and control daily salt consumption, the population attributable risk of the percentage of the incidence of disease that is due to salt was calculated using the following equation:

$$
\begin{gathered}
\text { Population attributable risk } \%=\mathrm{P}_{\mathrm{e}} \times(\mathrm{RR}-1) / \\
{\left[\mathrm{P}_{\mathrm{e}} \times(\mathrm{RR}-1)+1\right]}
\end{gathered}
$$

where, $\mathrm{P}_{\mathrm{e}}$ is the proportion of the population exposed to the risk factor (salt in this case) and RR is the relative risk of the risk factor (salt).

\section{Results}

Several interventions such as modifications of existing standards or adoption of new standards have been implemented in the country based on the international recommendations of daily intakes of: $<5 \mathrm{~g}$ of salt, $<10 \%$ total energy intake from saturated fatty acids and $<1 \%$ total energy intake from trans-fats (10). We identified eight food items that make up a large share of the daily Iranian food basket and three that make up a small share. As shown in Table 1, 17 standards were identified for these food products, 15 of which were selected for further assessments after removing duplications.

\section{Interventions on salt}

Since 2015, the Iran Food and Drug Administration has taken action on bread, doogh (Iranian fermented drink) and cheese as the major sources of salt intake in the country. No new standards have been developed for these food items. As shown in Table 2, three standards were revised with regard to the permitted level of salt in each food item. The permitted percentage of salt in bread was gradually reduced from $1.8 \%$ to $1.0 \%$ to adapt consumer taste, a decrease of $44 \%$. With regard to foods that make up a small share of the daily food basket, a new national standard was established and implemented in 2015 on the amount of edible salt in food products such as canned foods, tomato pastes, processed olives, sauces and pickles (16). In addition, salt use was banned in probiotic yoghurts in 2018 (15).

Based on epidemiological data, the relative risks of cardiovascular diseases and stroke associated with salt are 1.14 and 1.23, respectively (26). The population attributable risk of both diseases in the Islamic Republic of Iran before the modified salt standards were implemented was calculated. For the analysis, $\mathrm{Pe}=97.66 \%$ was used based on a previous study (27). Therefore, population attributable risk \% was $12.03 \%$ for cardiovascular disease and $18.34 \%$ for stroke before the modified standards.

\section{Interventions on oils}

To follow WHO recommendations, a number of restric- 


\begin{tabular}{|c|c|c|c|c|}
\hline Component & Food pro & & $\begin{array}{c}\text { New } \\
\text { standard }\end{array}$ & $\begin{array}{l}\text { Modified } \\
\text { standard }\end{array}$ \\
\hline Salt & Large share (Ref.) & Small share (Ref.) & & \\
\hline & Bread $(11,12)$ & & - & 2 \\
\hline & 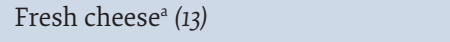 & & - & 1 \\
\hline & Doogh (Iranian fermented drink) (14) & & - & 1 \\
\hline & & Probiotic yoghurt (15) & - & 1 \\
\hline & & Other products ${ }^{\mathrm{b}}(16)$ & 1 & - \\
\hline Oil & & & & \\
\hline Trans/saturated fat & $\begin{array}{l}\text { Frying oil (household \& industry use) } \\
\text { (17) }\end{array}$ & & - & 1 \\
\hline & Semisolid oil for household use (18) & & - & 1 \\
\hline & $\begin{array}{l}\text { Table margarine and spread } \\
\text { margarine (19) }\end{array}$ & & - & 1 \\
\hline & Minarine \& sweetened minarine ${ }^{c}(20)$ & & - & 1 \\
\hline & & Shortening (21) & - & 1 \\
\hline Palm oil & $\begin{array}{l}\text { Cheese (fresh cheese }{ }^{a} \text {, lactic cheese, } \\
\text { pre-cheese) }(13,22,23)\end{array}$ & & - & 3 \\
\hline & $\begin{array}{l}\text { Butter (pasteurized butter, spread } \\
\text { butter) }(24,25)\end{array}$ & & - & 2 \\
\hline & Minarine ${ }^{c}(20)$ & & - & 1 \\
\hline
\end{tabular}

\section{Ref. $=$ reference.}

${ }^{a}$ Similar standards have been developed for both indices.

${ }^{b}$ Examples are canned foods, tomato paste, processed olives, sauces and pickles.

'Similar standards have been developed for both indices.

tions have been imposed on oil products in the Islamic Republic of Iran since 2015. The trans fat level was reduced to $2 \%$ and saturated fat level to $30 \%$ in final oil products for household use. For frying oils added to food products in industry and minarine (a cream-like product used in confectionary), higher saturated fat levels were allowed compared with household products (Table 3). Moreover, higher maximum permitted levels of trans and saturated fats were set for shortening because it is directly used in oil industries and makes a negligible contribution to daily food baskets (Table 3).

Annual palm oil imports were restricted in the country in 2014, leading to a drop in imports from 750000 tons in 2013 to about 465000 tons in 2017 (unpublished report). Furthermore, import tariffs on palm oil increased substantially from $2-4 \%$ in 2013 to $26-40 \%$ in 2016 (unpublished report). Production of analogue foods using vegetable oils such as analogue cheese and butter, and addition of palm kernel oil/palm stearin to minarine have been banned since 2015 .

\section{Nutritional traffic light}

A nutritional traffic light system has been designed using three colours - green, orange and red - to indicate low, medium and high levels of ingredients, respectively (Table 4). Calculation of amounts and assigning the colours for each food was based on the quantities per $100 \mathrm{~g}$ of solid foods, $100 \mathrm{~mL}$ of liquid foods or the serving size. If the serving size is less than $100 \mathrm{~g}$ or $150 \mathrm{~mL}$, the levels under heading of per $100 \mathrm{~g} / 100 \mathrm{~mL}$ are used. Otherwise, the levels in the last column (per serving size) must be used. Then, if the product does not match with the last column, the colour is selected by converting the quantity per $100 \mathrm{~g}$ or $100 \mathrm{~mL}$ and using numbers of other columns (28). As shown in Figure 1, the amounts of a parameter are calculated and inserted in the food label.

Since early 2016, nutritional traffic light labelling on food packages is mandatory for all imported and

Table 2 Changes in maximum permitted percentage of salt in foods that make up a large share of foods bought and consumed

\begin{tabular}{lcccc}
\hline Food (reference) & Before (\%) & After (\%) & Decrease (\%) & Base year \\
Bread (11,12) & 1.8 & 1.0 & 44 & $2016-2017$ \\
Cheese (13) & 4.0 & 3.0 & 25 & 2015 \\
Doogh (Iranian fermented drink) (14) & 1.0 & 0.8 & 20 & 2015 \\
\hline
\end{tabular}




\begin{tabular}{|c|c|c|c|c|}
\hline \multirow[t]{2}{*}{ Product (Ref.) } & \multicolumn{2}{|c|}{ Trans fat (\%) } & \multicolumn{2}{|c|}{ Saturated fat (\%) } \\
\hline & Before 2015 & After 2015 & Before 2015 & After 2015 \\
\hline \multicolumn{5}{|l|}{ Household use } \\
\hline Frying oil (17) & 2 & 2 & No limits & 30 \\
\hline Semisolid oil (18) & 5 & 2 & 30 & $30 a$ \\
\hline Table margarine (19) & 10 & 2 & 40 & 48 \\
\hline Spread margarine (19) & 5 & 2 & 30 & 35 \\
\hline Minarine (20) & 5 & 2 & No limits & 60 \\
\hline \multicolumn{5}{|l|}{ Industry use } \\
\hline Frying oil (17) & 2 & 2 & No limits & 45 \\
\hline Minarine (20) & 5 & 2 & No limits & 60 \\
\hline Shortening (21) & 10 & 5 & No limits & 65 \\
\hline
\end{tabular}

Ref. = reference.

${ }^{a}$ This further decreased to $25 \%$ in 2018

domestic foods, except for products that are not chemically processed or formulated, such as vegetables, spices, vinegar, lemon juice, tea, infusions, coffee, honey, dates, flour and barberry.

\section{Discussion}

Unhealthy diet is one of the four behavioural risk factors associated with NCDs (6). As people of all ages are more likely to be exposed to this risk factor than the other three (tobacco use, harmful use of alcohol and physical inactivity), food interventions to reduce the intake of certain products to safer levels have been instigated by countries.

\section{Salt evidence}

Salt is necessary for normal body function and food preservation. Nonetheless, excessive daily salt intake results in diseases such as high blood pressure, cardiovascular diseases and gastric cancers (29,30). For example, sodium intake of $3480 \mathrm{mg} /$ day, equal to $8.8 \mathrm{~g} /$ day of salt, was the main contributor to cardiometabolic diseases, mainly in elderly people, in the United States of America (31). This intake is similar to the daily intake of salt in the Islamic Republic of Iran in 2016 - $9.52 \mathrm{~g}$ (27). Based on the clinical adverse effects, WHO has recommended a maximum salt intake of $5 \mathrm{~g} /$ day, which allows normal function of the human body with no adverse effects on health (32). Since the national salt intake in the Islamic Republic of Iran was about twice the WHO recommended level, regulatory authorities brought in new restrictions. Mandatory reformulation of popular foods is the most cost-effective approach to decreasing disease burdens associated to salt (33-35). Therefore, we examined salt content of and regulations on staple foods such as bread, cheese and doogh.

The Iran national survey on average daily consumption of food reported a daily consumption of $310 \mathrm{~g}$ of bread, $16 \mathrm{~g}$ of cheese and $6 \mathrm{~g}$ of doogh per capita (36). Based on these data, it is estimated that $2.65 \mathrm{~g} /$ day of salt has been removed from the food of every Iranian after the adoption of new interventions in 2017. Therefore, the current salt intake is estimated to be $6.87 \mathrm{~g} /$ day. We also showed that $12 \%$ of cardiovascular diseases and $18 \%$ of strokes could be attributed to high salt intake in 2016 (before the regulations). Therefore, large decreases in these diseases are expected in coming years as a result of the reduction in salt intake through staple foods. It is worth noting that the daily salt intake is still higher than that recommended by WHO and further restrictions through reformulations are not practical because of technical limitations. For example, other than the flavour and preservative roles of salt, addition of salt to dough for bread baking is responsible for texture due to the electrostatic interactions between amino acids and effects on hydration of proteins (37). Therefore, to achieve further reduction in salt intake, consumers' awareness of their salt consumption should be promoted. About 50$60 \%$ of daily salt intake is from salt that is directly added

\begin{tabular}{|c|c|c|c|c|c|c|c|c|}
\hline \multirow[t]{2}{*}{ Index } & \multicolumn{2}{|c|}{ Low level } & \multicolumn{2}{|c|}{ Medium level } & \multicolumn{4}{|c|}{ High level } \\
\hline & Per $100 \mathrm{~g}$ & $\begin{array}{c}\text { Per } \\
100 \mathrm{~mL}\end{array}$ & Per $100 \mathrm{~g}$ & Per 100 mL & Per $100 \mathrm{~g}$ & $\begin{array}{c}\text { Per } \\
100 \mathrm{~mL}\end{array}$ & Per & ng size \\
\hline Salt & $\leq 0.3$ & $\leq 0.3$ & $>0.3$ to $\leq 1.5$ & $>0.3$ to $\leq 0.75$ & $>1.5$ & $>0.75$ & $>1.8$ & $>0.9$ \\
\hline Sugar & $\leq 5$ & $\leq 2.5$ & $>5$ to $\leq 22.5$ & $>2.5$ to $\leq 11.25$ & $>22.5$ & $>11.25$ & $>27$ & $>13.5$ \\
\hline Fat & $\leq 3$ & $\leq 1.5$ & $>3$ to $\leq 17.5$ & $>1.5$ to $\leq 8.75$ & $>17.5$ & $>8.75$ & $>21$ & $>10.5$ \\
\hline Trans fatty acid & $\leq 0.5$ & $\leq 0.5$ & $>0.5$ to $\leq 2$ & $>0.5$ to $\leq 2$ & $>2$ & $>2$ & $>2$ & $>2$ \\
\hline
\end{tabular}

$100 \mathrm{~g}$ is used for solid foods and $100 \mathrm{~mL}$ for liquid foods. 
Figure 1 Nutritional traffic light label used for food products in the Islamic Republic of Iran

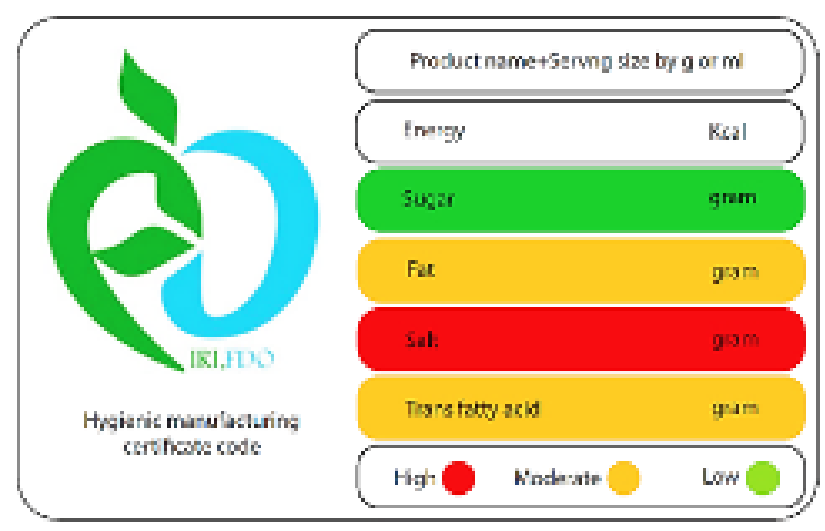

to food by the consumer (38), which is currently equal to 3.44-4.12 g/day in the Islamic Republic of Iran.

\section{Oil evidence}

WHO recommends that less than $1 \%$ and $10 \%$ of total dietary energy intake per day should come from trans and saturated fats, respectively (39). Cardiovascular diseases impose heavy financial burdens on governments annually because of productivity losses and health care expenses (40). Other than salt contribution, the high cardiovascular disease rates are possibly due to the consumption of saturated and trans fats $(41,42)$. Trans fats have further hazards as they can induce thrombogenesis and atherogenesis (41,42). Despite previous reports, new findings have shown that ruminant-produced and industrial trans fatty acids adversely change the ratio of low-density lipoprotein cholesterol to high-density lipoprotein cholesterol in the human body (43). However, the adverse effects of industrial fatty acids are greater than those of ruminant isomers in normal diets. This effect possibly occurs because of the presence of bioactive components and nutrients in ruminant-derived foods containing trans fats (43). Therefore, lower intake of these two fatty acids or their substitution with cis unsaturated fatty acids results in healthier blood lipid profiles (43). Moreover, iso-caloric substitution of saturated fatty acids with cis unsaturated fatty acids, particularly polyunsaturated fatty acids, results in lower rates of cardiovascular diseases and significant decreases in low-density lipoprotein and total cholesterol $(40,44)$. Studies have also shown the negative role of saturated fatty acids in type 2 diabetes as saturated fatty acids from milk and liquid oils increased the overall risk of type 2 diabetes (45).

Previously, the main source of trans isomers for humans included partially hydrogenated oils (46). However, the use of these oils has decreased because of the evidence of their clinical adverse effects $(41,42)$. In the Islamic Republic of Iran, similar to other countries, restrictions on the production of partially hydrogenated oils have led to further use of palm oil because of its cost-effectiveness. However, high levels of saturated fatty acids, such as palmitic acid in palm oil and the known carcinogenicity of monochloropropane diol esters which is mainly formed in palm oil during the refining processes (47), were important health concerns. Therefore, the Iran Food and Drug Administration aimed to decrease saturation levels of fats by requiring industries to use other vegetable oils. The main strategy was setting a maximum permitted saturation in popular household frying oils which previously was not limited, and similar policies were adopted for industrial frying oils. As a result, addition of palm oil to foods was restricted in national food industries and people's exposures to the hazardous compounds decreased to safe levels. Today, Iranian oil industries use various oil fractions to produce food products under the modified regulations. For example, they use emulsifiers in the mixture of unsaturated vegetable oils with small portions of fully hydrogenated oils to prepare healthier semisolid formulations compared with partially hydrogenated oils. These mixtures consist of about $70 \%$ common vegetable oils such as canola and sunflower, up to $25 \%$ of palm olein and a maximum $5 \%$ of fully hydrogenated oils. Therefore, recent formulations contain higher unsaturation rates and reduced levels of trans and saturated fatty acids compared with earlier formulations.

\section{Nutritional traffic light}

According to the Codex Alimentarius, "labeling includes any written, printed or graphic matter that is present on the label, accompanies the food or is displayed near the food including that for the purpose of promoting its sale or disposal" (48). To minimize the negative contribution of overweight and obesity to NCDs, simple policies to inform consumers, including nutritional labelling, were introduced for preventive purposes in the Islamic Republic of Iran. Nutritional labelling helps consumers to choose healthy products within various commercial brands based on their daily food baskets and calorie intakes. This strategy also helps the government to control NCDs and reduce budgets for medical care as a result of NCDs. Experiences in other countries show that nutritional traffic light labelling is a preferred method compared with other labelling guides such as octagons, nutritional claims, logos and numerical levels per serving sizes (49). Therefore, design of graphical feature showing total calorie, salt, sugar, fat and trans-fat indices was motivated by Iran FDA. Despite similar targets of nutritional labelling by different countries (50), differences exist in the details in the labels. For example, most countries include the total calorie, fat, sugar and salt in foods (50); however, level of trans fat was also added to the nutritional traffic light by the Iran Food and Drug Administration because of the clear involvement of trans fatty acids in cardiovascular diseases in the country.

Studies that assessed the effectiveness of nutritional traffic light labelling on food selection have shown that raising consumer awareness and knowledge would increase the effects of such interventions (51,52). Thus, the Iran Food and Drug Administration ran a health campaign to introduce the nutritional traffic light 
labelling to people. The campaign included educational programmes at schools, interviews in the media and public advertisements. However, this is the beginning of nutritional traffic light labelling in the country and further research must be carried out on consumer perceptions to have a better understanding of effectiveness of this policy.

\section{Conclusion}

The Islamic Republic of Iran is a large country with a variety of cultures and dietary behaviours. Our study shows that, in addition to revising food product regulations and encouraging the food industry to reformulate food products, behavioural modifications should be considered by consumers to reduce their risk of NCDs as a result of their diet. In the Islamic Republic of Iran, salt levels in various foods, as well as saturated and trans fatty acids in oil products, decreased through implementation of new national strategies. Furthermore, nutritional traffic light labelling was established as a strategy to raise public awareness. Further studies are needed to assess the effectiveness of these interventions in reducing NCDs in the Islamic Republic of Iran.

\section{Acknowledgement}

We thank Dr. Heshmatollah Razavi Mousavi, Mr. Hooman Mohammad Raoufi, Mrs Zohreh Pourahmadi (from Iran Food and Drug Administration) and staff of the Iran National Standards Organization for their contribution in preparation of the adopted policies.

Funding: None.

Competing interests: Dr. Mehrnaz Kheirandish was Director General for Department of Assessment and Control of Prescribing and Use of Medicines and Health Products at Iran FDA from 2016 to 2020. Dr. Masoumeh Moslemi and Dr. Atefeh Fooladi Moghaddam worked at Iran FDA and Mr. Nader Karimian Khosroshahi currently works at Iran FDA. Dr. Hedayat Hosseini, Dr. Behrooz Jannat and Dr. Vahid Mofid were Director General for Department of Foods and Beverages at Iran FDA from 2012 to 2015, 2016 to 2017 and 2018 to 2019, respectively."

\section{Les politiques alimentaires nationales de la République islamique d'Iran visant la prévention et la maîtrise des maladies non transmissibles.}

\section{Résumé}

Contexte : Le régime alimentaire joue un rôle important dans le risque de contracter des maladies non transmissibles. Après la publication du plan d'action de l'Organisation mondiale de la Santé (OMS) sur la prévention et la maîtrise des maladies non transmissibles, des activités nationales ont été mises en route en République islamique d'Iran.

Objectifs : La présente étude décrit les politiques alimentaires nationales mises en œuvre par le gouvernement afin de lutter contre les maladies non transmissibles dans le pays conformément au plan d'action de l'OMS.

Méthodes : Les normes et réglementations alimentaires récemment adoptées, liées aux maladies non transmissibles de 2013 à 2018, ont été examinées et les teneurs maximales autorisées en sel et en graisses saturées et en acides gras trans ont été comparées dans les anciennes et les nouvelles normes. Le système de feux tricolores pour l'étiquetage nutritionnel visant à sensibiliser le public aux régimes alimentaires sains a été évalué.

Résultats: Quinze normes alimentaires associées à huit produits alimentaires qui constituent une grande partie du panier alimentaire quotidien iranien et trois qui en constituent une petite partie ont été évaluées. Les politiques relatives au sel comprennent la réduction du pourcentage maximum autorisé dans le pain, le fromage et le doogh (une boisson fermentée) à $1 \%, 3 \%$ et $0,8 \%$, respectivement. En ce qui concerne les graisses saturées et les acides gras trans, les pourcentages maximums autorisés des huiles et graisses comestibles ont été fixés respectivement à $2-5 \%$ et 30 $65 \%$. L'étiquetage nutritionnel aux feux tricolores, qui indique les teneurs en sel, sucre, graisses et acides gras trans des aliments, est obligatoire pour tous les aliments depuis 2016.

Conclusions : Les politiques mises en œuvre pour réduire la teneur en sel et en graisses/huiles des aliments devraient entraîner une baisse significative des maladies non transmissibles dans les années à venir dans le pays. Cependant, des études supplémentaires sont nécessaires pour démontrer l'efficacité des interventions. 


\section{السياسات الغذائية الوطنية في جمهورية إيران الإسلامية الر امية إلى مكافحة الأمر اض غير السارية والوقاية منها \\ معصو مة مسلمي، مهرناز خيراندش، رامين نجاد فرد، هداية حسيني، بهروز جنات، وحيد مفيد، عاطف مقدم، نادر كريميان

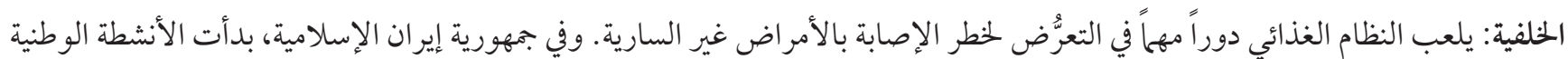

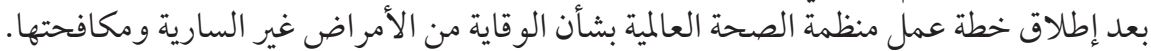

الأهداف: هدفت هذه الدراسة إلى توضيح السياسات الغذائية الوطنية التي تنفذها الحكومة من أجل الحدِّّ من الأمراض غير السارية في البلاد وَفْقاً لخطة عمل منظمة الصحة العالمية.

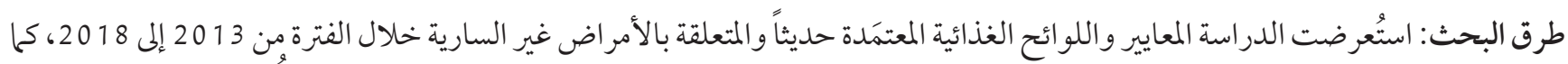

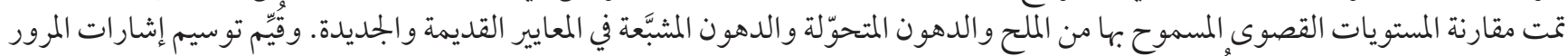
التغذوية لإذكاء الوعي العام بالنّظم الغذائية الصمحية.

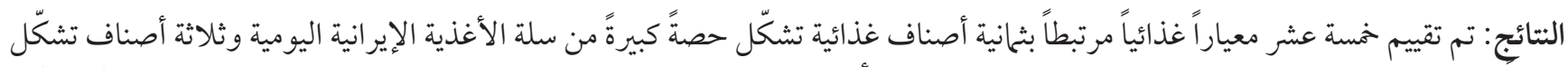

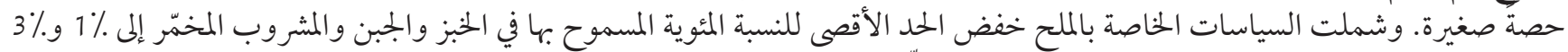

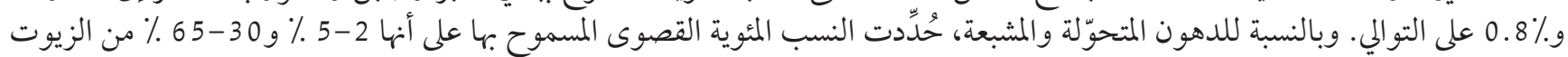

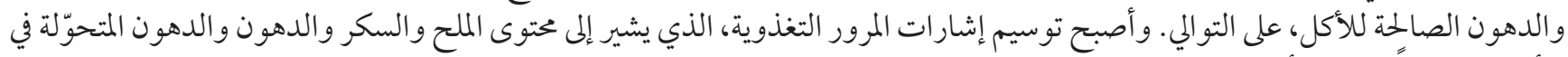

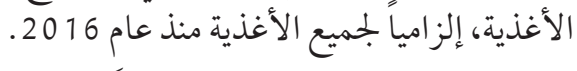

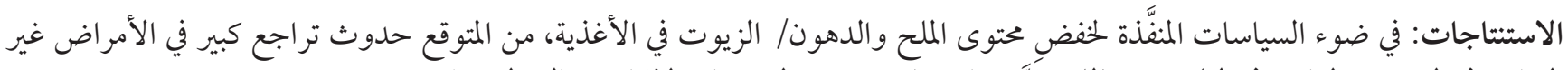

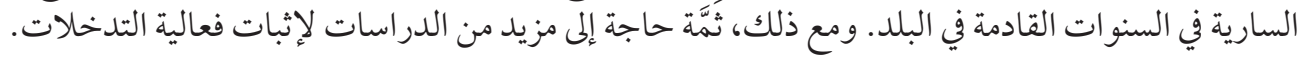

\section{References}

1. Noncommunicable diseases. Geneva: World Health Organization; 2018 (WHO Fact sheet; http://www.who.int/mediacentre/factsheets/fs355/en/, accessed July 2019).

2. Iran (Islamic Republic of). Geneva: World Health Organization; 2018 (Country profiles; http://www.who.int/nmh/countries/ irn_en.pdf?ua=1/, accessed July 2018).

3. Peykari N, Hashemi H, Dinarvand R, Haji-Aghajani M, Malekzadeh R, Sadrolsadat A, et al. National action plan for non-communicable diseases prevention and control in Iran; a response to emerging epidemic. J Diabetes Metab Disord. 2017;16(3):1-7. https:// doi.org/10.1186/s40200-017-0288-4

4. Hawkes C, Popkin BM. Can the sustainable development goals reduce the burden of nutrition-related non-communicable diseases without truly addressing major food system reforms? BMC Med. 2015;13:143. https://doi.org/10.1186/s12916-015-0383-7

5. Baker P, Friel S. Processed foods and the nutrition transition: evidence from Asia. Obes Rev. 2014;15:564-77. https://doi.org/10.1111/ obr.12174

6. Global action plan for the prevention and control of noncommunicable diseases 2013-2020. Geneva: World Health Organization; 2013 (https://apps.who.int/iris/bitstream/handle/10665/94384/9789241506236_eng.pdf?sequence=1, accessed July 2019).

7. Augustin MA, Riley M, Stockmann R, Bennett L, Kahl A, Lockett T, et al. Role of food processing in food and nutrition security. Trends. Food Sci Technol. 2016;56:115-25. https://doi.org/10.1016/j.tifs.2016.08.005

8. [National Action Plan for Prevention and Control of Non-Communicable Diseases and the Related Risk Factors in the Islamic Republic of Iran, 2015-2025.] Tehran: Ministry of Health and Education; 2015 [In Farsi].

9. Crino M, Sacks G, Wu JH. A review of population-level actions targeting reductions in food portion sizes to address obesity and related non-communicable diseases. Curr Nutr Rep. 2016;5:323-32. https://doi.org/10.1007/s13668-016-0181-7

10. Healthy diet. Geneva: World Health Organization; 2018 (WHO Fact sheet; https://www.who.int/news-room/fact-sheets/detail/ healthy-diet/, accessed July 2019).

11. [Traditional breads: specifications and test methods. INSO A1-2628. Amendment No. 1.] Tehran: Iranian National Standardization Organization; 2016 [In Farsi] (http://standard.isiri.gov.ir/StandardView.aspx?Id=46303, accessed 25 February 2020).

12. [Bulk breads-specifications and test methods. INSO 2338. Second revision.] Tehran: Iranian National Standardization Organization; 2017 [In Farsi] (http://standard.isiri.gov.ir/StandardView.aspx?Id=49200, accessed 25 February 2020).

13. [Milk and milk products - fresh cheese: specifications and test methods. INSO 6629. First revision.] Tehran: Iranian National Standardization Organization; 2015 [In Farsi] (http://standard.isiri.gov.ir/StandardView.aspx?Id=41550, accessed 25 February 2020).

14. [Production and expiration date of dairies. Circular letter 122509/675. FB-Ci-1394-0107.] Tehran: Iran Food and Drug Administration; 2015 [In Farsi]. 
15. [Probiotic yoghurt: specifications and test methods. INSO A2-11325. Amendment No. 2.] Tehran: Iranian National Standardization Organization; 2018 [In Farsi] (http://standard.isiri.gov.ir/StandardView.aspx?Id=49953, accessed 25 February 2020).

16. [Food additives: the amount of edible salt in food products - permitted limits. INSO 19917. First edition.] Tehran: Iranian National Standardization Organization; 2015 [In Farsi] (http://standard.isiri.gov.ir/StandardView.aspx?Id=40028, accessed 25 February 2020).

17. [Edible fats and oils - frying oil: specifications and test methods. INSO 4152. Second revision.] Tehran: Iranian National Standardization Organization; 2016 [In Farsi] (http://standard.isiri.gov.ir/StandardView.aspx?Id=46413, accessed 25 February 2020).

18. [Consumer edible vegetable oil: specifications and test methods. INSO 9131. First revision.] Tehran: Iranian National Standardization Organization; 2015 [In Farsi] (http://standard.isiri.gov.ir/StandardView.aspx?Id=44637, accessed 25 February 2020).

19. [Vegetable butter (margarine): specifications and test methods. INSO 143. Fifth revision.] Tehran: Iranian National Standardization Organization; 2015 [In Farsi] (http://standard.isiri.gov.ir/StandardView.aspx?Id=43121, accessed 25 February 2020).

20. [Edible fats and oils - minarine: specifications and test methods. INSO 10500. First revision.] Tehran: Iranian National Standardization Organization; 2015 [In Farsi] (http://standard.isiri.gov.ir/StandardView.aspx?Id=43120, accessed 25 February 2020).

21. [Edible oils and fats - bakery and shortening: specifications and test methods. INSO 156-1. Third revision.] Tehran: Iranian National Standardization Organization; 2015 [In Farsi] (http://standard.isiri.gov.ir/StandardView.aspx?Id=42939, accessed 25 February 2020).

22. [Lactic cheese: specifications and test methods. INSO 13863.] Tehran: Iranian National Standardization Organization; 2016 [In Farsi] http://standard.isiri.gov.ir/StandardView.aspx?Id=38961, accessed 25 February 2020).

23. [Milk and milk prouducts - pre-cheese: specifications and test methods. INSO 13418.] Tehran: Iranian National Standardization Organization; 2017 [In Farsi] (http://standard.isiri.gov.ir/StandardView.aspx?Id=47440, accessed 25 February 2020).

24. [Pasteurized butter: specifications and test methods. INSO 162. 2.] Tehran: Iranian National Standardization Organization; 2016 [In Farsi] (http://standard.isiri.gov.ir/StandardView.aspx?Id=42933, accessed 25 February 2020).

25. [Dairy spread: specifications and test methods. INSO 10084.] Tehran: Iranian National Standardization Organization; 2016 [In Farsi] (http://standard.isiri.gov.ir/StandardView.aspx?Id=802, accessed 25 February 2020).

26. Strazzullo P, D’Elia L, Kandala NB, Cappuccio FP. Salt intake, stroke, and cardiovascular disease: meta-analysis of prospective studies. BMJ. 2009;339:1-9. https://doi.org/10.1136/bmj.b4567

27. Rezaei S, Mahmoudi Z, Sheidaei A, Aryan Z, Mahmoudi N, Gohari K, et al. Salt intake among Iranian population: the first national report on salt intake in Iran. J Hypertens. 2018;36(12):2380-9. http//:doi.org/10.1097/HJH.0000000000001836

28. Guide to creating a front of pack (FoP) nutrition label for pre-packed products sold through retail outlets. 2013. London: Department of Health; 2013 (https://assets.publishing.service.gov.uk/government/uploads/system/uploads/attachment_data/file/566251/ FoP_Nutrition_labelling_UK_guidance.pdf, accessed 25 February 2020).

29. Cappuccio FP, Campbell NR. Population dietary salt reduction and the risk of cardiovascular disease: A commentary on recent evidence. J Clin Hypertens. 2017;19(1):4-5. https://doi.org/10.1111/jch.12917

30. Stomach (gastric) cancer prevention ( $\mathrm{PDQ}^{\circledR}$ ). Health professional version. Bethesda (MD): National Cancer Institute; 2002-2019 (http://www.ncbi.nlm.nih.gov/pubmed/26389263, accessed 25 February 2020).

31. Micha R, Penalvo JL, Cudhea F, Imamura F, Rehm CD, Mozaffarian D. Association between dietary factors and mortality from heart disease, stroke, and type 2 diabetes in the United States. JAMA. 2017;317(9):912-24. http://doi.org/10.1001/jama.2017.0947

32. Guideline: sodium intake for adults and children. Geneva: World Health Organization; 2012 (https://www.who.int/nutrition/publications/guidelines/sodium_intake_printversion.pdf, accessed 25 February 2020).

33. Kypridemos C, Guzman-Castillo M, Hyseni L, Hickey GL, Bandosz P, Buchan I, et al. Estimated reductions in cardiovascular and gastric cancer disease burden through salt policies in England: an IMPACTNCD microsimulation study. BMJ Open. 2017;7(1):e013791. http://dx.doi.org/10.1136/bmjopen-2016-013791

34. Temme EH, Hendriksen MA, Milder IE, Toxopeus IB, Westenbrink S, Brants HA, et al. Salt reductions in some foods in The Netherlands: monitoring of food composition and salt intake. Nutrients. 2017;9(7):1-17. http//:doi.org/10.3390/nu9070791

35. Quader ZS, Zhao L, Gillespie C, Cogswell ME, Terry AL, Moshfegh A, et al. Sodium intake among persons aged $\geq 2$ years - United States, 2013-2014. MMWR. Morb Mortal Wkly Rep. 2017;66(12):324-8. http://dx.doi.org/10.15585/mmwr.mm6612a3

36. [National food consumption survey. Iran]. Tehran: National Nutrition and Food Technology Research Institute; 2004:1-73 [In Farsi].

37. Abedi E, Majzoobi M, Farahnaky A, Pourmohammadi K, Mahmoudi MR. Effect of ionic strength ( $\mathrm{NaCl}$ and $\mathrm{CaCl} 2)$ on functional, textural and electrophoretic properties of native and acetylated gluten, gliadin and glutenin. Int J Biol Macromol. 2018;120(Pt B):2035-47. https://doi.org/10.1016/j.ijbiomac.2018.09.155

38. Kholdi N, Pouraram H, Pirasteh A, Abtahi M. Readiness for behavioral change of discretionary salt intake among women in Tehran, Iran. BioRxiv. 1 June 2018 (preprint). http://dx.doi.org/10.1101/336628

39. Diet, nutrition and the prevention of chronic diseases: report of a joint WHO/FAO expert consultation. Geneva: World Health Organization; 2003 1-149 (https://apps.who.int/iris/bitstream/handle/10665/42665/WHO_TRS_916.pdf;jsessionid=BC39A33E5FD798A5C826B6B147D6711B?sequence=1, accessed 25 February 2020). 
40. Te Morenga L, Montez JM. Health effects of saturated and trans-fatty acid intake in children and adolescents: Systematic review and meta-analysis. PLoS One. 2017;12(11):1-20. https://doi.org/10.1371/journal.pone.0186672

41. Jeyarani T, Reddy SY. Preparation of plastic fats with zero trans FA from palm oil. J Am Oil Chem Soc. 2003;80(11):1107-13. https:// doi.org/10.1007/s11746-003-0827-5

42. Prielinger E. Relationship between diet, lifestyle and cardiovascular disease risk within European countries [thesis]. Vienna: University of Vienna; 2008. (http://othes.univie.ac.at/3822/1/2009-03-03_0202572.pdf, accessed 25 February 2020).

43. Hutchinson J, Rippin HL, Jewell J, Breda JJ, Cade JE. Comparison of high and low trans-fatty acid consumers: analyses of UK National Diet and Nutrition Surveys before and after product reformulation. Public Health Nutr. 2018;21(3):465-79. https://doi. org/10.1017/S1368980017002877

44. Molenberg FJ, De Goede J, Wanders AJ, Zock PL, Kromhout D, Geleijnse JM. Dietary fatty acid intake after myocardial infarction: a theoretical substitution analysis of the Alpha Omega Cohort. Am J Clin Nutr. 2017;106(3):895-901. http://doi.org/10.3945/ ajcn.117.157826

45. Liu S, Van Der Schouw YT, Soedamah-Muthu SS, Spijkerman AM, Sluijs I. Intake of dietary saturated fatty acids and risk of type 2 diabetes in the European Prospective Investigation into Cancer and Nutrition-Netherlands cohort: associations by types, sources of fatty acids and substitution by macronutrients. Eur J Nutr. 2019;58(3):1125-36. http://doi.org/10.1007/s00394-018-1630-4

46. Wang FC, Gravelle AJ, Blake AI, Marangoni AG. Novel trans fat replacement strategies. Curr Opin Food Sci. 2016;7(2):27-34. https://doi.org/10.1016/j.cofs.2015.08.006

47. Razak RAA, Tarmizi AHA, Hammid ANA, Kuntom A, Ismail IS, Sanny M. Verification and evaluation of monochloropropanediol (MCPD) esters and glycidyl esters in palm oil products of different regions in Malaysia. Food Addit Contam Part A. 2019;36(11):1626-36. https://doi.org/10.1080/19440049.2019.1654139

48. Codex general standard for the labelling of pre-packaged foods. Codex Alimentarius; 1985:1-9 (http://www.fao.org/3/Y2770E/ y2770e02.htm, accessed 25 February 2020)

49. Instituto Nacional de Salud Publica de México. Review of current labelling regulations and practices for food and beverage targeting children and adolescents in Latin America countries (Mexico, Chile, Costa Rica and Argentina) and recommendations for facilitating consumer information. New York: UNICEF; 2016 (http://incap.int/index.php/es/listado-de-documentos/repositorio-efan/documentos-tecnicos-efan/369-review-of-current-labelling-regulations-and-practices-for-food-and-beverage-targeting-children-and-adolescents-in-latin-america-countries-mexico-chile-costa-rica-and-argentina-and-recommendations-for-facilitating-consumer-information/file, accessed 25 February 2020).

50. Global update on nutrition labelling. Brussels: European Food Information Council; 2018 (https://www.eufic.org/images/uploads/ healthy-living/Executive-Summary-GUNL-2018-V2.pdf, accessed 25 February 2020).

51. Sacks G, Rayner M, Swinburn B. Impact of front-of-pack 'traffic-light'nutrition labelling on consumer food purchases in the UK. Health Promot Int. 2009;24(4):344-52. http//:doi.org/10.1093/heapro/dapo32

52. Sonnenberg L, Gelsomin E, Levy DE, Riis J, Barraclough S, Thorndike AN. A traffic light food labeling intervention increases consumer awareness of health and healthy choices at the point-of-purchase. Prev Med. 2013;57(4):253-7. http//:doi.org/10.1016/j. ypmed.2013.07.001 